\title{
Pengaruh Pemberian Angkak Monascus purpureus terhadap Kualitas Mikrobiologis Feses Tikus Putih Hiperlipidemia
}

\section{The Influence of "angkak" Monascus purpureus on the of Microbiology Quality of Hyperlipidemia White Rats Faeces}

\author{
T Yulinery*, R. Hardiningsih, dan N. Nurhidayat \\ Bidang Mikrobiologi, P2B LIPI Jl.Raya Bogor Jakarta km 46 Cibinong \\ E-mail: tyulinery@yahoo.co.id *Penulis untuk korespondensi
}

\begin{abstract}
Angkak is defined as rice fermented by Monascus purpureus, a lovastatin and pigmen producer. The objective of this research was to observe the effect of angkak powder to the digestion system represented by the quality of faeces. The in vivo bioassay was carried out using 20 SpragueDawley strain mice into 5 groups. First group was given angkak respectively $0.01 \mathrm{~g}, 0.1 \mathrm{~g}, 0.5 \mathrm{~g}$, and two groups of control (positive and negative). The faeces were examined each week for a month. The number or erytrosit, bacteria, and fungus were examined microscopically. The results showed that $0,01 \mathrm{~g}, 0,1 \mathrm{~g}, 0,5 \mathrm{~g}$ of angkak did not significantly affect of bacteria, fungus and erythrocyte on faeces. The data suggest that the administration of angkak might be useful and safe for the hypercholestrolemic treatment.
\end{abstract}

Key words: Lovastatin, white rats faeces, bacteria, kapang, eritrosit

\begin{abstract}
Abstrak
Penelitian ini dilakukan untuk mengetahui pengaruh pemberian angkak terhadap saluran pencernaan sehingga diharapkan tidak memberikan efek negatif terhadap saluran pencernaan. Penelitian dilakukan secara in vivo pada tikus putih galur Sprague-Dawley, jenis kelamin jantan sebanyak 20 ekor. Perlakuan terhadap tikus dibagi menjadi 5 kelompok, yaitu kelompok yang diberi 0,01g angkak, 0,1g angkak, 0,5g angkak, dan 2 kelompok kontrol (positif dan negatif). Penelitian dilakukan selama 4 minggu dan pengambilan feses tiap 7 hari. Feses diperiksa secara mikroskopis dan kuantitasi mikroba untuk melihat jumlah eritrosit, koloni bakteri dan jamur. Hasil penelitian menunjukkan bahwa pemberian angkak pada dosis $0,01 \mathrm{~g}, 0,1 \mathrm{~g}$, dan $0,5 \mathrm{~g}$ tidak memengaruhi secara nyata terhadap konsistensi jumlah koloni bakteri, jamur dan eritrosit pada feses, sehingga penggunaan angkak aman bagi saluran pencernaan konsumen.
\end{abstract}

Kata kunci: Lovastatin, feses, bakteri, jamur, eritrosit

Diterima: 27 Maret 2009, disetujui: 16 Desember 2009

\section{Pendahuluan}

Secara alami, Monascus purpureus memproduksi senyawa yang dapat menghambat sintesis kolesterol yang dikenal dengan lovastatin (Stancu dan Sima, 2002) atau monakolin K (Ma et al., 2000; Hajjaj et al., 2001) atau mevinolin. Ketiga senyawa tersebut merupakan senyawa obat yang banyak digunakan untuk menurunkan kadar kolesterol dalam darah melalui penghambatan enzim HMG KoA reduktase, yaitu enzim yang mengontrol jalur biosintesis kolesterol (Su et al., 2003).
Senyawa ini bersifat inhibitor kompetitif yaitu penghambat enzim yang berkompetisi dengan substrat untuk berikatan dengan sisi aktif enzim, dan apabila terikat tidak dapat diubah oleh enzim tersebut (Appelkvist et al., 1993).

Mekanisme penghambatan sintesis kolesterol oleh lovastatin melalui salah satu komponen dari struktur lovastatin yang analog dengan HMG KoA yang akan diubah menjadi asam mevalonat dengan bantuan enzim HMG KoA reduktase. Sifat analog dari lovastatin dapat berkompetisi dengan HMG KoA untuk berikatan dengan enzim HMG KoA reduktase (Goldstein and Brown, 1990; Parker et al., 1993). Bila 
jumlah lovastatin cukup besar untuk berikatan dengan enzim HMG KoA reduktase, asam mevalonat sebagai senyawa antara sintesis kolesterol tidak akan terbentuk sehingga pembentukan kolesterol menjadi terhambat.

Pengobatan hiperlipidemia dengan lovastatin murni biasanya dilakukan peroral, tetapi dengan diketahuinya angkak (serbuk Monascus purpureus) mengandung lovastatin serta sulitnya isolasi lovastatin maka memungkinkan penggunaan langsung angkak peroral sebagai obat antihiperlipidemia.

Lovastatin diabsorpsi melalui rute peroral kira-kira 30\%, mengalami efek lintasan pertama melalui hati. Obat ditemukan dalam plasma sebagai metabolit aktif atau inaktif. Obat dan metabolitnya terikat pada protein plasma sebanyak $95 \%$. Sebagian besar produk degradasi diekskresi melalui feses dan kurang dari $10 \%$ melalui urin (Ganiswarna, 1995).

Penggunaan angkak yang mengandung lovastatin telah banyak digunakan sebagai obat (Wild et al., 2002). Hal ini dapat memengaruhi keseimbangan flora normal pada saluran pencernaan, karena angkak yang diberikan berupa spora jamur yang hidup. Dalam saluran pencernaan jamur dapat berkembang biak dan bisa menimbulkan efek yang merugikan atau yang menguntungkan bagi tubuh. Efek samping lovastatin terjadi pada kurang dari $10 \%$ penderita menunjukkan gangguan saluran pencernaan, sakit kepala dan otot, letih dan rash (kemerahan), tetapi belum ada laporan efek toksik yang serius (Folkers et al., 1990). Lovastatin dosis tinggi menimbulkan katarak pada lensa mata anjing, walaupun hal ini belum terjadi pada manusia.

Mikroba usus yang bermanfaat bagi proses pencernaan, antara lain Lactobacillus (Goossens et al., 2005), Escherichia coli, Enterobacter aerogenes dan Enterococci mampu membentuk asam laktat, mensintesis vitaminvitamin tertentu seperti vitamin $\mathrm{k}$, biotin dan vitamin B-kompleks. Mikroflora penghuni saluran pencernaan manusia menyusun suatu ekosistem yang kompleks dan terdiri dari sekitar $10^{14}$ bakteri dari 400-500 spesies (Goldin et al., 1994). Idealnya mikroba-mikroba tersebut tidak boleh terganggu oleh adanya $M$. purpureus yang berlebihan dalam sistem pencernaan. Oleh karena itu, perlu diteliti kualitas mikroba usus setelah pemberian angkak peroral.
Kolon atau usus besar mengandung populasi mikroba terbanyak dalam tubuh manusia. Diperkirakan $\pm 10^{12}$ organisme terdapat pada spesimen tinja per gram $(50-60 \%$ dari berat kering bahan tinja dapat terdiri dari bakteri dan mikroba lain). Orang dewasa mengekskresikan $3 \times 10^{13}$ bakteri setiap hari di dalam fesesnya, kebanyakan dari sel-sel tersebut tidak hidup (Pelczar dan Chan, 1988).

Bakteri anaerob 300 kali lebih banyak dibanding anaerob fakultatif seperti Escherichia coli di dalam usus besar. Bacillus gram negatif anaerob yang ada meliputi spesies Bacteroides dan Fusobacterium, bacillus gram negatif meliputi spesies Clostridium, Lactobacilus, Eubacterium, Bifidobacterium. Spesies-spesies anaerob fakultatif yang dijumpai dalam usus tergolang genus Escherichia, Proteus, Klebsiella dan Enterobacter. Peptostreptococcus dan khamir Candida albicans juga umum dijumpai di usus (Todar, 2008).

Usus kecil bagian atas (usus dua belas jari) mengandung beberapa bakteri, di antaranya adalah kokus dan bacillus gram positif. Di dalam jejunum kadang kala dijumpai spesies-spesies Enterococcus, Lactobacillus juga Candida albicans. Pada ileum, mikroorganisme mulai menyerupai yang dijumpai pada usus besar.

Bakteri umum yang ada pada orang dewasa yang sehat yaitu bakteri anaerob seperti Bacteroides, Eubacterium, Bifidobacterium dan Peptostreptococcus, jumlahnya $10^{9}-10^{11} / \mathrm{g}$ feses. Disamping itu sejumlah coliform, Enterococci, Lactobacillus dan Veillonella $10^{5}-10^{8} / \mathrm{g}$ feses, sedangkan bacili, Staphylococcus dan yeast kurang dari $10^{5} / \mathrm{g}$ feses (Mitsuoka, 1996).

Bakteri yang umum pada mencit dan tikus adalah Lactobacillus dan bakteri anaerob. Coliform dan Enterococci lebih banyak terdapat pada tikus daripada mencit. Pada usus tikus, Lactobacillus jumlahnya banyak sedangkan Bifidobacterium tidak dijumpai (Mitsuoka, 1996).

Bakteri Coliform, Enterococcus, dan Bacillus akan berkurang dalam tubuh manusia dan hewan. Jika manusia dan hewan berada di lingkungan yang bersih, dan jumlah Bifidabacterium dan Lactobacillus lebih dominan di dalam tubuh. Berdasarkan hal di atas, dilakukan penelitian yang bertujuan mengetahui perubahan konsistensi feses setelah pemberian angkak Monascus purpureus yang 
mengandung lovastatin selama kurun waktu satu bulan pada tikus putih.

Penelitian ini diharapkan dapat memberikan informasi pengaruh pemberian angkak (serbuk $M$. purpureus) terhadap konsistensi feses, sehingga tidak memberikan efek samping yang merugikan terhadap saluran pencernaan sehingga aman untuk dikonsumsi.

\section{Metode Penelitian}

\section{Pembuatan Angkak dari M. purpureus}

Biakan M. purpureus diinokulasi dalam media MEA (Difco) miring dan diinkubasi pada suhu $30^{\circ} \mathrm{C}$ selama 14 hari. Kemudian di buat suspensi askospora dan dimasukkan kedalam $25 \mathrm{~g}$ nasi steril, diaduk rata dan diinkubasi selama 14 hari pada suhu $30^{\circ} \mathrm{C}$. Inokulum tersebut dikeringkan pada suhu $45^{\circ} \mathrm{C}$, kemudian digerus sampai menjadi serbuk (Yulinery et al., 2006).

\section{Persiapan Hewan Percobaan}

Penelitian ini menggunakan tikus putih jantan jenis Sprague dawley berumur 2 bulan. Tikus dikondisikan/diadaptasikan selama 2 minggu terhadap makanan, minuman dan lingkungannya, dan diberi pakan standar sebanyak $20 \mathrm{~g} / \mathrm{ekor}$ setiap hari. Tikus yang sakit ditandai dengan kurangnya aktivitas, lebih banyak diam dan bulu-bulu berdiri tidak diikutsertakan dalam penelitian.

\section{Perlakuan terhadap Tikus Putih}

Tikus putih dibagi dalam 5 kelompok, terdiri dari kontrol negatif diberi pakan standar, kontrol positif diberi pakan mengandung kolesterol (kolesterol 1,5\% dari kuning telur, lemak kambing $10 \%$, minyak kelapa $1 \%$, pakan standar 83\%) (Kuswinarti dan Sugiono, 1990) dan 3 kelompok perlakuan (mengandung lovastatin dan kolesterol). Tikus dipuasakan selama 16 jam, berat badan ditimbang dan feses diambil untuk diperiksa. Tiap kelompok diberi serbuk angkak secara oral menggunakan sonde oral, yaitu: 1) Kelompok A (perlakuan): diberi pakan mengandung kolesterol (20 g), angkak yang mengandung lovastatin $(0,01 \mathrm{~g})$ dan $1 \mathrm{ml}$ larutan PTU 0,01\%. 2) Kelompok B (perlakuan): diberi pakan mengandung kolesterol (20 g), angkak yang mengandung lovastatin $(0,1 \mathrm{~g})$ dan
$1 \mathrm{ml}$ larutan PTU 0,01\%. 3) Kelompok C (perlakuan): diberi pakan mengandung kolesterol (20 g), angkak yang mengandung lovastatin (0,5 g) dan $1 \mathrm{~mL}$ larutan PTU 0,01\%. 4) Kelompok D (kontrol positif): diberi pakan mengandung kolesterol (20 g) dan $1 \mathrm{~mL}$ larutan PTU 0,01\%. 5) Kelompok E (kontrol negatif) : diberi pakan standar $(20 \mathrm{~g})$ dan $1 \mathrm{~mL} \mathrm{NaCl}$ fisiologis

Tikus putih diberi perlakuan setiap hari dan dilakukan pengamatan keadaan umum. Penimbangan berat badan dilakukan setiap 3 hari dan pengambilan feses untuk diperiksa dilakukan setiap 7 hari.

\section{Pengambilan Feses Tikus}

Feses diambil langsung dari kandang dan diletakkan dalam pot tertutup rapat, bersih dan kering. Pengambilan feses tikus dilakukan setiap 7 hari selama 1 bulan. Feses yang diambil harus segar dan tidak boleh disimpan terlalu lama.

\section{Pemeriksaan Feses}

\section{Secara Mikroskopis}

Feses diambil dibagian tengah/permukaan yang mengandung darah/lendir, diletakkan pada kaca objek yang telah ditetesi larutan eosin $2 \%$ diaduk sampai rata kemudian ditutup dengan kaca penutup. Pengamatan berupa adanya eritrosit (sel darah merah), diamati di bawah mikroskop (Gandasoebrata, 1984).

\section{Kuantitasi Mikroba : Hitungan Cawan}

Semua perlakuan dikerjakan secara aseptik. Diambil 1 gram feses dan dimasukkan kedalam tabung yang telah berisi $9 \mathrm{ml}$ akuades steril, lalu dibuat pengenceran secara seri sampai $10^{6}$. Dipipet $0,1 \mathrm{ml}$ sampel dari tiap-tiap tabung pengencer dimasukkan kedalam cawan berisi medium tauge agar (gula $60 \mathrm{~g}$, agar $10 \mathrm{~g}$ dan dilarutkan dalam 11 ekstrak tauge) dan cawan yang telah berisi medium LB (triptona $10 \mathrm{~g}$, yeast ekstrak $5 \mathrm{~g}, \mathrm{NaCl} 5 \mathrm{~g}$, agar $10 \mathrm{~g}$, aquadest ad 11) kemudian diinkubasi pada suhu $30^{\circ} \mathrm{C}$ selama 3 hari dan jumlah koloni pada masing-masing cawan dihitung (Maturin dan Peeler, 2001). Hasil pengamatan diolah dengan menggunakan uji statistik (ANOVA) menggunakan Rancangan Acak Lengkap (RAL) (Matjik dan Sumartajaya, 2000). 


\section{Hasil dan Pembahasan}

\section{Kondisi Fisik Tikus}

Berat badan kelompok perlakuan mengalami kenaikan walaupun pada minggu pertama mengalami sedikit penurunan, ini disebabkan tikus memerlukan adaptasi terhadap makanan yang diberikan (pakan mengandung kolesterol). Demikian juga berat badan kelompok kontrol mengalami peningkatan yang stabil tetapi pada minggu ke-4 terjadi penurunan berat badan, kemungkinan tikus mengalami stres akibat lamanya perlakuan sehingga nafsu makannya sedikit berkurang dan asupan protein yang memegang peranan penting dalam semua sel untuk menjalankan berbagai fungsi dan mengatur sebagian besar aktivitas fisik dan kimia yang penting bagi tubuh (MacGregor, 2000) menjadi berkurang (Gambar 1).

Kelompok perlakuan dengan $0,01 \mathrm{~g}$ angkak (A) mengalami peningkatan berat badan sampai akhir perlakuan, kelompok perlakuan dengan 0,1 g angkak (B) mengalami penurunan berat badan pada minggu ke-2 dan kembali naik sampai minggu ke-4. Kelompok perlakuan dengan $0,5 \mathrm{~g}$ angkak (C) mengalami penurunan berat badan pada minggu ke-1, kemudian naik sampai akhir perlakuan. Penurunan berat badan ini karena berbagai faktor, di antaranya efek pemberian propil tiourasil (PTU) setiap hari pada kelompok tersebut. PTU adalah suatu zat antitiroid yang menghambat biosintesis tiroksin, sehingga sintesis protein yang memerlukan tiroksin terganggu (Martin et al., 1987). Hal ini mengakibatkan pertumbuhan tikus terhambat. Faktor lain yang menyebabkan penurunan berat badan adalah variasi jumlah pakan yang dikonsumsi tikus (Yulinery et al., 2006).

\section{Jumlah Koloni Bakteri}

Secara statistik, semua kelompok perlakuan menunjukkan pengaruh yang berbeda nyata $(\mathrm{P}<0,05)$. Hasil pengamatan jenis-jenis bakteri yang ditemukan pada feses yakni bakteri Staphylococcus sp. dan Bacillus sp. Gambar 2 terlihat variasi jumlah bakteri dalam feses tikus putih sebelum dan sesudah perlakuan. Sebelum perlakuan, jumlah bakteri semua kelompok tidak homogen yaitu berkisar $(50-300) \times 10^{7} \mathrm{CFU} / \mathrm{mL}$.

Pada akhir perlakuan (minggu ke-4) terjadi penurunan jumlah koloni bakteri pada kelompok A (0,01 angkak), B (0,1g angkak), dan $\mathrm{C}(0,5 \mathrm{~g}$ angkak) terhadap awal perlakuan (minggu ke-0). Kelompok A jumlah koloni bakteri menurun $98,52 \%$, kelompok B menurun 99,03\% dan kelompok C menurun 98,99\% (Gambar 3). Hal ini disebabkan oleh perlakuan terjadi penurunan jumlah bakteri karena kelebihan dari pigmen angkak adalah dapat membunuh bakteri (bakterisidal) atau menghambat pertumbuhan bakteri (bakteriostatik) (Blanc et al., 1995), sedangkan perlakuan kelompok E (kontrol negatif) terjadi peningkatan sebesar 13,64\%.

\section{Jumlah Koloni Jamur}

Perubahan jumlah koloni jamur selama masa perlakuan dapat dilihat pada Gambar 4. Sebelum perlakuan (minggu ke-0), jumlah koloni jamur bervariasi pada tiap-tiap kelompok yaitu $(1-35)$ x $10^{5}$ Propagul/ $\mathrm{mL}$.

Setelah masa perlakuan (minggu ke-4), terjadi penurunan jumlah koloni jamur pada kelompok A (0,01g angkak), B (0,1g angkak), dan C ( $0,5 \mathrm{~g}$ angkak) bila dibandingkan kelompok D (kontrol positif) yang mengalami kenaikan jumlah koloni jamur. Kelompok A, B, dan C mengalami penurunan $98,44 \%, 100 \%$, dan $100 \%$ dibandingkan minggu awal perlakuan (minggu ke-0), sedangkan kelompok D meningka $975 \%$ (Gambar 5). Hal ini disebabkan jamur $M$. purpureus mengandung glikosida yang mempunyai efek antimikroba, terhadap bakteri maupun jamur pada saluran pencernaan. Blanc et al., (1995) menyatakan, angkak mengandung beberapa senyawa selain lovastatin, yaitu asamasam lemak tidak jenuh, protein, asam amino, fitosterol, isoflavon, dan glikosidanya, serta berbagai pigmen. Kandungan senyawa tersebut memengaruhi flora normal saluran pencernaan baik menguntungkan maupun merugikan, Wang et al.,(2002) melaporkan bahwa strain Monascus purpureus CCRC31499 dari 5 strain Monascus purpureus, mempunyai aktivitas anti jamur yang maksimal terhadap Fusarium oxysporum dan stabil pada $\mathrm{pH}$ 6-8. Secara statistik, semua kelompok perlakuan menunjukkan pengaruh yang tidak berbeda nyata $(p>0,05)$. Hasil pengamatan menunjukkan jenis-jenis jamur yang ditemukan pada feses tikus yakni jamur Mucor sp., Rhizopus sp. dan Aspergillus sp. 


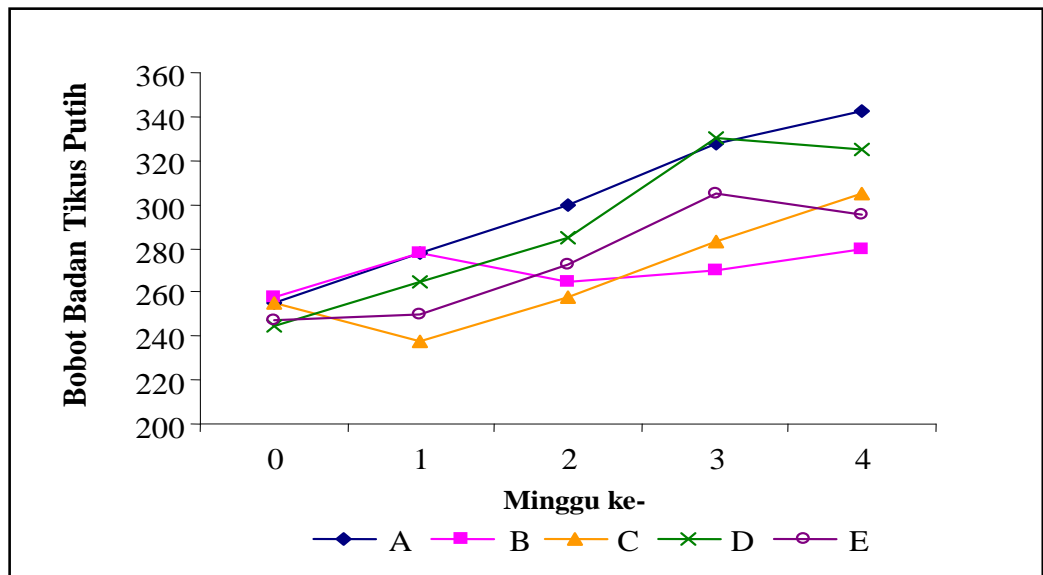

Gambar 1. Perkembangan bobot badan tikus selama masa perlakuan.

Keterangan: A) Kelompok dengan 0,01 g angkak. B) Kelompok dengan $0,1 \mathrm{~g}$ angkak. C) Kelompok dengan 0,5 g angkak. D) Kelompok kontrol positif. E) Kelompok kontrol negatif.

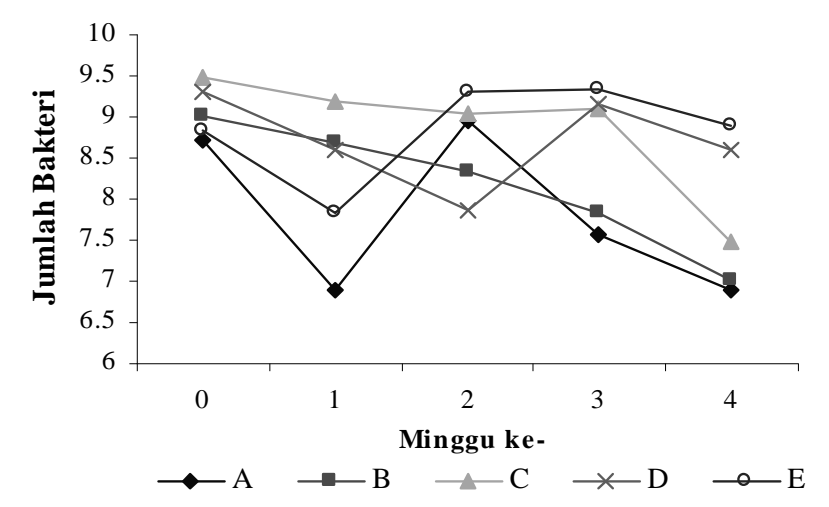

Gambar 2. Perubahan jumlah koloni bakteri selama masa perlakuan. Keterangan: A) Kelompok dengan 0,01 g angkak. B. Kelompok dengan $0,1 \mathrm{~g}$ angkak. C) Kelompok dengan $0,5 \mathrm{~g}$ angkak. D) Kelompok kontrol positif. E) Kelompok kontrol negatif.

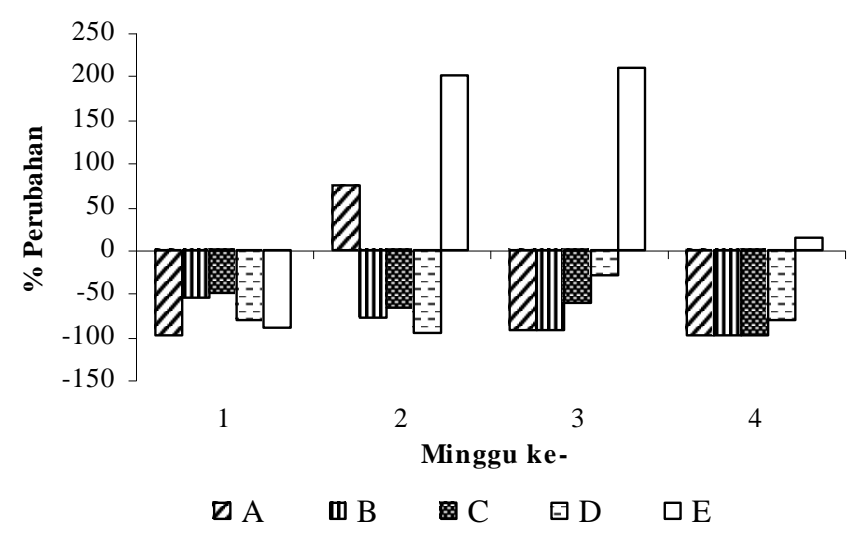

Gambar 3. Persen perubahan jumlah koloni bakteri selama masa perlakuan. Keterangan: A) Kelompok dengan 0,01g angkak. B) Kelompok dengan $0,1 \mathrm{~g}$ angkak. C) Kelompok dengan 0,5 g angkak. D) Kelompok kontrol positif. E) Kelompok kontrol negatif. 


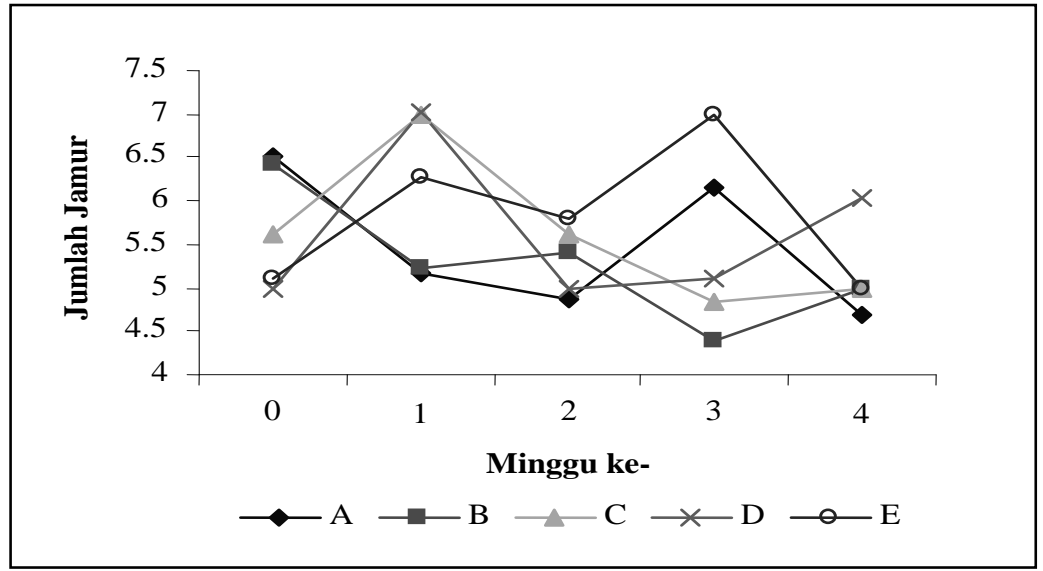

Gambar 4. Perubahan jumlah koloni jamur selama masa perlakuan.

Keterangan: A) Kelompok dengan 0,01 g angkak B) Kelompok dengan

$0,1 \mathrm{~g}$ angkak. C) Kelompok dengan 0,5 g angkak D)

Kelompok kontrol positif. E) Kelompok kontrol negatif.

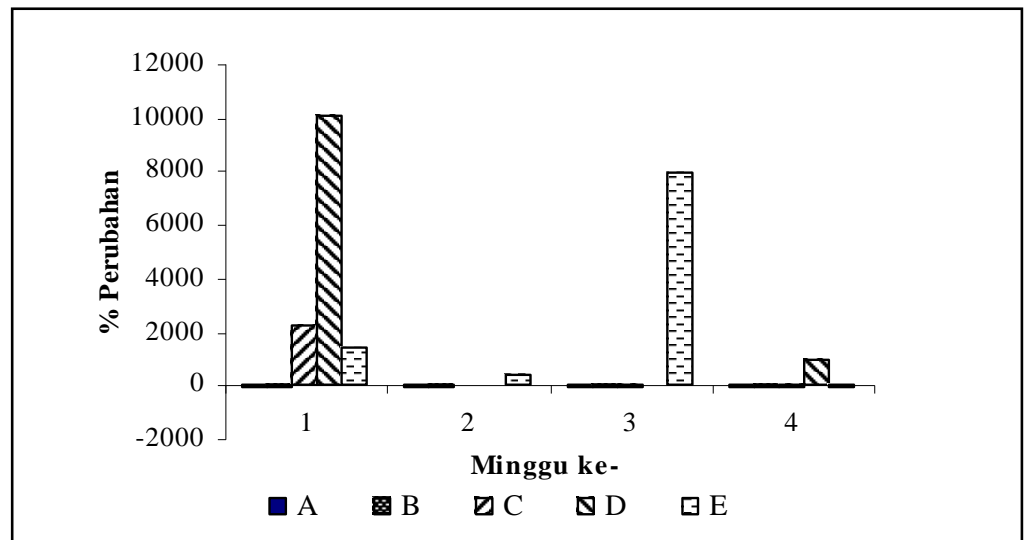

Gambar 5. Persen perubahan jumlah koloni jamur selama masa perlakuan.

Keterangan: A) Kelompok dengan 0,01 g angkak. B) Kelompok dengan $0,1 \mathrm{~g}$ angkak. C) Kelompok dengan 0,5 g angkak. D) Kelompok kontrol positif. E) Kelompok kontrol negatif.

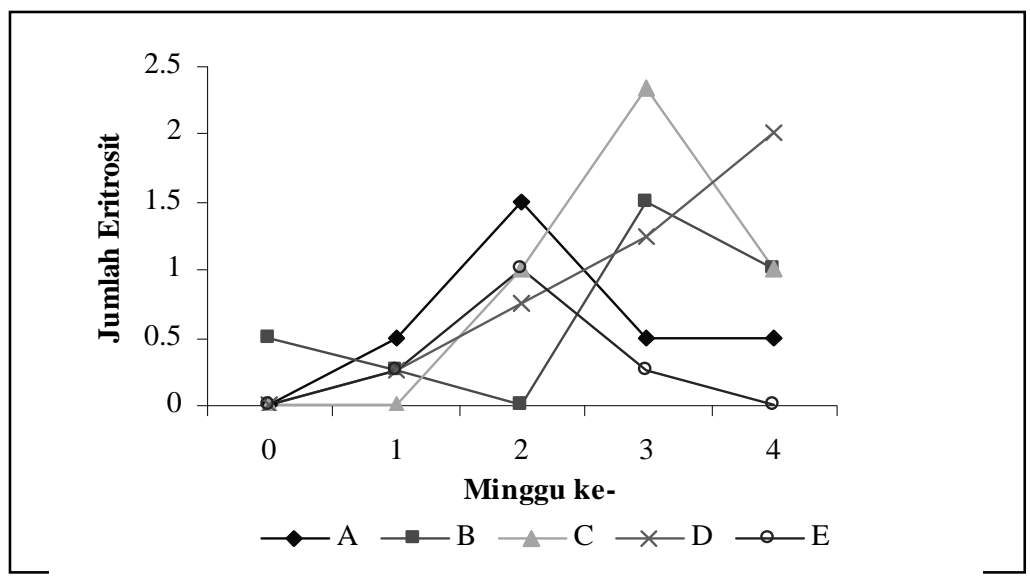

Gambar 6. Perubahan jumlah eritrosit selama masa perlakuan.

Keterangan: A) Kelompok dengan 0,01 g angkak. B) Kelompok dengan

$0,1 \mathrm{~g}$ angkak. C) Kelompok dengan 0,5 g angkak. D) Kelompok kontrol positif. E) Kelompok kontrol negatif. 


\section{Jumlah Eritrosit}

Perubahan jumlah eritrosit dalam feses selama masa perlakuan dapat dilihat pada Gambar 6. Sebelum masa perlakuan, jumlah eritrosit dalam feses semua kelompok relatif homogen, yaitu berkisar 0-0,5 /LPB (Lapang Pandang Besar).

Setelah masa perlakuan (minggu ke-4), hampir semua kelompok mengalami kenaikan jumlah eritrosit terutama pada minggu ke-2, yaitu berkisar 0,75-1,5 LPB, kecuali kelompok B (0,1 g angkak) mengalami perubahan jumlah eritrosit yang cukup signifikan, terlihat pada minggu ke-2 jumlah eritrosit mengalami penurunan dari minggu ke-0 sampai minggu ke2 , yaitu dari 0,25 menjadi 0 . Namun setelah minggu ke-2 jumlah eritrosit kelompok B mengalami kenaikan yang sangat tajam yaitu 1,5 , begitu pun kelompok $\mathrm{C}(0,5 \mathrm{~g}$ angkak) mengalami kenaikan jumlah eritrosit yang sangat tajam pada minggu ke-3 yaitu 2,33.

Jika dilihat dari persen perubahan jumlah eritrosit (Gambar 7) yang dibandingkan dengan minggu ke-0, nilainya tidak mengalami perubahan yang berarti yaitu 0 , kecuali pada kelompok B pada minggu ke-3 mencapai $200 \%$. Analisis statistik pada perlakuan ini menunjukkan pengaruh yang berbeda nyata $(\mathrm{p}<0,05)$.

Adanya eritrosit dalam feses kemungkinan disebabkan beberapa faktor seperti terbentuknya radikal bebas dari metabolisme lipid, radikal bebas tersebut menyebabkan terjadinya proses peradangan pada saluran pencernaan berupa pelebaran pembuluh darah yang menyebabkan eritrosit ke luar di samping itu juga disebabkan oleh iritasi mukosa saluran cerna sehingga dapat terjadi pendarahan. Radikal bebas memicu terjadinya lipid peroksidasi berupa peningkatan asam lambung oleh radikal bebas sehingga selsel menjadi terakumulasi dan merusak mukosa gaster (Anonim, 2008). Namun, jumlah eritrosit dalam feses pada semua kelompok sampai minggu ke-4 masih dalam batas normal yaitu 0-1 LPB, sehingga tidak memengaruhi kondisi dari tikus itu sendiri.

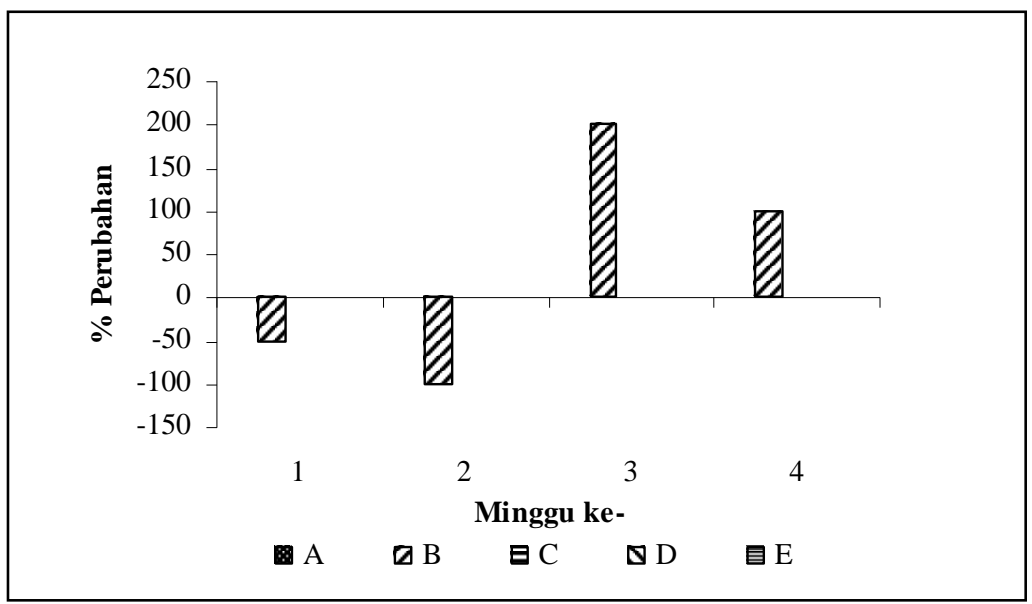

Gambar 7. Persen perubahan jumlah eritrosit selama masa perlakuan. Keterangan: A) Kelompok dengan 0,01 g angkak. B) Kelompok dengan $0,1 \mathrm{~g}$ angkak. C) Kelompok dengan 0,5 g angkak. D) Kelompok kontrol positif. E) Kelompok kontrol negatif.

\section{Simpulan dan Saran}

\section{Simpulan}

Berdasarkan uraian di atas dapat disimpulkan bahwa pemberian angkak $M$. purpureus tidak memengaruhi feses tikus putih, pemberian angkak tidak memberikan efek samping yang merugikan terhadap saluran pencernaan.

\section{Saran}

Perlu dilakukan penelitian lanjutan terhadap hispatologi saluran pencernaan. 


\section{Ucapan Terima Kasih}

Terima kasih dan penghargaan penulis sampaikan kepada Pusat Penelitian Biologi LIPI atas bantuan dana penelitian ini melalui Proyek DIPA.

\section{Daftar Pustaka}

Anonim. 2008. http://mataharihati.multiply.com/reviews/ item/39. 05/19/2008.

Appelkvist, E.L., Edlund, C., Low, P., Schedin, S., Kalen, A. dan Dallner, G. 1993. Effects of Inhibitors of Hydroxymethylglutaryl Coenzyme A Reductase on Coenzyme Q and Dolichol Biosynthesis. $J$ Clin Invest, 71: S97-102.

Blanc, P., Laussac, J.P., Le Bars, J., Le Bars, P., Loret, M.O., Pareilleux, A., Prome, D., Prome, J.C., Santerre, A.L. dan Goma, G. 1995. Characterization of Monascidin A from Monascus as Citrinin. Int. J. Food Microbiol, 27: 201-213.

Folkers, K., Langsjoen, P., Willis, R., Richardson, P., Xia, L.J., Ye, C.Q. dan Tamagawa, H. 1990. Lovastatin Decreases Coenzyme Q Levels in Human. Proc Natl Acad Sci USA, 87 (22): 8931-8934.

Gandasoebrata, R. 1980. Penuntun Laboratorium Klinik Penerbit Dian Rakyat.

Ganiswarna, G.S. 1995. Farmakologi dan Terapi. Edisi ke4. Bagian Farmakologi Fakultas Kedokteran Universitas Indonesia, Jakarta.

Goldin, B.R., Leichtein, A.H. dan Gorbach, S.L. 1994. Nutritonal and Metabolic Roles of Intestinal Flora. Modern Nutrition in Health and Disease. In: Shils, Olson and Shike (Eds.). Lea and Febiger, Philadelphia.

Golstein, J.L. dan Brown, M.S. 1990. Regulation of the Mevalonate Pathway. Nature, 343: 425-430.

Goossens, D., Jonkers, D., Russel, M., Thijs, A., van den Bogaard, A., Stobberingh, E. dan Stockbrugger, R. 2005. Survival of Probiotic, L. Plantarum 299v and its Effect on the Faecal Bacterial Flora, With and Without Gastric Acid Inhibition. Dig Liver Dis, 37 (1): 3-6.

Hajjaj, H., Neiderberger, P. dan Duboc, P. 2001. Lovastatin Biosynthesis by Aspergillus tereus in a Chemically Defined Medium. App.Env. Microbiol, 67: 2596-2602.

Kuswinarti dan Sugiono, NC. 1990. Efek Ekstrak Temu Giring (Curcuma Heynae val \& v Zijp) terhadap Konsentrasi Kolesterol Darah Tikus Jantan. Phyto Medica, 1: 120-127.
Ma, J., li, Y., Ye, Q., li, J., Hua, Y., ju, D., Zhang, D., Cooper, R. dan Chang, M. 2000. Constituents of Red Yeast Rice, a Tradisional Chinese Food and Medicine. J. Agric. Food Chem, 48: 5220-5225.

MacGregor, EA. 2000. Polymers in Nature. John wiley \& Sons. New York.

Matjik, M. dan Sumartajaya, M. 2000. Rancangan Percobaan, Bogor; IPB Press.

Martin, D.W. 1987. Harper's Review of Biochemistry. Edisi ke-20. Terjemahan: Dr. Iyan Darmawan. Penerbit Buku Kedokteran EGC, Jakarta.

Mitsuoka, T. 1996. Intestinal Flora and Human Health. Asia Pacific. J. Clin. Nutr, 5 (1): 2-9.

Maturin, L. dan Peeler, J.T. 2001.Bacteriological Analytical Manual, Edition 8, Chapter 3. Aerobic Plate Count.

Parker, R.A., Pearce, B.C., Clark, R.W., Gordon, D.A. dan Wright, J.J.K. 1993. Tocotrienol Regulate Cholesterol Production in Mammalian Cells by Post-Transcriptional Suppression of 3-hydroxy3-methylglutaryl Coenzymea Reductase. $J$. Biol.Chem, 268: 11298-11238.

Pelczar, M.J. dan Chan, E.C.S. 1988. Dasar-Dasar Mikrobiologi 2. Cetakan I. Alih bahasa, Ratna Siri Hadioetomo et al., Universitas Indonesia Press, Jakarta.

Stancu, C. dan Sima, A. 2002. Statins: Mechanism of Action and Effects. J. Cell. and Mol. Med., Review Oct-Dec 2001. JCMM "Carol Davila" University Press. Romania.

Su, Y.C., Wang, J.J., Wang, T.T., Lin dan Pan, T.M. 2003. Production of Secondary Metabolites $\gamma$ Aminobutyric Acid and Monacolin K by Monascus. J. Ind. Microbiol. Biotechnol, 30: 41-46.

Todar, K. 2008. Todar's on Line Textbook of Bacteriology. p:1-3. http://textbook of bacteriology.net/ normalflora_3.html. 01/29/2009.

Wang, S.L., Yen, Y.H., Tsiao, W.J. dan Wang, C.L. 2002. Production of Antimicrobial Compounds by Monascus Purpureus CCRC1499 Using Shrimp and Crab Shell Powder as a Carbon Source. Enzyme and Microbial Tecnology, 31: 337-344.

Wild, D., Toth, G. dan Humpf, H.U. 2002. New Monascus Metabolite Isolated from Red Yeast Rice (angkak, red koji). J. Agric.Food Chem, 50: 3999-4002.

Yulinery, T., Hardiningsih, R. dan Kasim, E. 2006. Pengaruh Pakan Kolesterol terhadap Bobot Badan Tikus Sprague dawley yang Diberi Monascus purpureus went Penurun Kolesterol. J. Ilmiah Pertanian Gakuryoku, 12 (2): 174-179. 